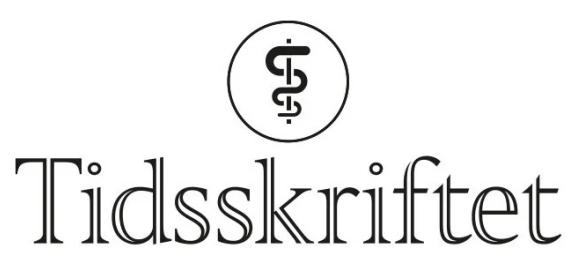

DEN NORSKE LEGEFORENING

\title{
Medisinsk kompetanse i framtiden
}

LEGELIVET

\section{CECILIE NORMANN BIRKELI}

cecilie.normann.birkeli@lefo.no

Legeforskningsinstituttet (LEFO)

\section{Pandemien har påvirket synet på medisinsk kompetanse.} Bør den også påvirke målene for medisinsk utdanning?

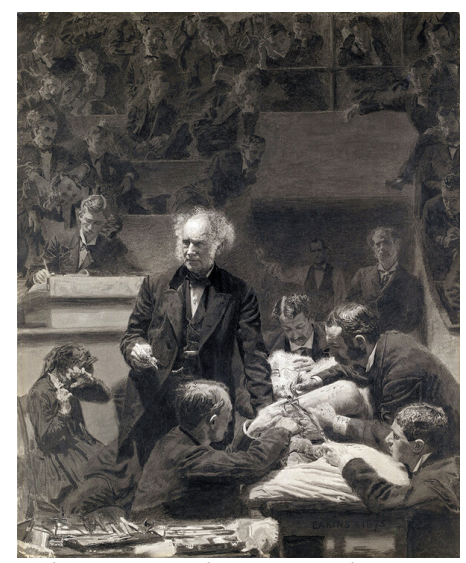

"The Gross Clinic» av Thomas

Eakins fra 1875 viser kirurgen

Samuel D. Gross som

underviser ved Jefferson

Medical College i

Philadelphia.

Bilderettigheter: NTB

Koronapandemien har satt helsetjenesten på prøve. Nye virusvarianter oppstår, kunnskapen om viruset utvikler seg stadig, og retningslinjer for behandling og smittevern endres. Medisinsk personell utfører oppgaver som tidligere ikke har vært forventet av dem, og som de ikke alltid er opplært i. Noen har engasjert seg med en gang, mens andre hverken vil eller kan. Hva påvirker de ulike valgene? Er de som engasjerer seg, også mest kompetente til å gjøre det?

\section{Vurdering av medisinsk kompetanse}


I en nylig publisert studie stilte forfatterne tolv spørsmål om revurdering av medisinsk kompetanse (1). De delte kompetansen i tre nivåer: individuelt (mikronivå), institusjonelt (mesonivå) og samfunnsmessig (makronivå). På mikronivå diskuteres medisinsk kompetanse fra opplæringskandidaters og legers perspektiv. Framtidens helsetjeneste vil trolig kreve at leger og annet helsepersonell tilpasser seg nye forhold på en smidigere måte enn mange ville ha forventet da de ble opplært. Ukjente problemstillinger kan kreve evne og mot til å ta initiativ og finne kreative løsninger. Hvor langt er legene villige til å gå for å tilpasse seg endringene og finne løsninger på ukjente problemstillinger, hvilke etiske vurderinger ligger bak disse valgene, og har de et moralsk ansvar?

«Bør man innføre midlertidige lisenser for personell uten den vanlige opplceringen, slik at de kan praktisere hvis det oppstår ekstraordincere behov?»

På mesonivå diskuteres medisinsk kompetanse ut fra institusjoner og lokale utdanningsprogrammer. Kan læreplanene bli mer dynamiske og tilpasses slik at de bedre gjenspeiler gjeldende kompetanse og beredskap for katastrofer?

På makronivå bør bruken av lisenser kanskje revurderes. Bør man for eksempel innføre midlertidige lisenser for personell uten den vanlige opplæringen, slik at de kan praktisere hvis det oppstår ekstraordinære behov? Og hvordan kan erfaringer med pandemien bidra til at man er bedre forberedt på neste krise?

\section{Hva er en kompetent lege?}

Definisjonen på en kompetent lege kan virke opplagt. Men den kan også gi rom for tolkning og presiserer ikke nødvendigvis hva som skal til for å utføre spesifikke oppgaver. I pandemien har også kompetente leger vært usikre, og de kan ha tatt personlig risiko i pasientbehandlingen. Forfatterne av studien mener at man må drøfte ressursene på alle tre plan ut fra den medisinske kompetansen som kreves. På denne måten kan man bli bedre forberedt og tilpasse seg raskere for å yte nødvendig helsehjelp når behovet oppstår.

\section{LITTERATUR}

1. ten Cate O, Schultz K, Frank JR et al. Questioning medical competence: Should the Covid-19 crisis affect the goals of medical education? Med Teach 2021; 43: 817-23. [PubMed][CrossRef]

Publisert: 31. januar 2022. Tidsskr Nor Legeforen. DOI: 10.4045/tidsskr.21.0887

Mottatt 13.12.2021, godkjent 17.12.2021.

(C) Tidsskrift for Den norske legeforening 2023. Lastet ned fra tidsskriftet.no 26. april 2023. 